\title{
Gender Differences in Work Motivation of Public Basic Education in Metro Vigan and Caoayan, Philippines and Job Satisfaction
}

\section{Theogenia Magallanes ${ }^{1}$, Damianus Abun ${ }^{2}$, Jacel Mansueto ${ }^{3}$, Nathanael Flores ${ }^{4}$}

\author{
${ }^{1}$ Ed.D, St. Benedict College of Northern Luzon, Philippines \\ ${ }^{2} \mathrm{Ph} . \mathrm{D}$, Divine Word College of Vigan and St. Benedict College of Northern Luzon \\ ${ }^{3}$ MA Ed, St. Benedict College of Northern Luzon, Philippines \\ ${ }^{4}$ St. Benedict College of Northern Luzon, Philippines
}

\begin{abstract}
The study wanted to determine the differences in work motivation and job satisfaction of male and female teachers and to determine the relationship between work motivation and job satisfaction. To carry out such purpose, related literatures and studies were reviewed to support the theory of the study and proper methodology was followed. The study used descriptive correlational method of research design and aided by fact finding inquiry. The population of the study were 263 teachers. of basic public schools of Metro Vigan and Caoayan. Validated Questionnaires were used to gather the data and to treat the data statistically, mean, $t$-test and Pearson $r$ were used. Mean was to measure the level of motivation and job satisfaction and t-test was used to measure the difference and Pearson $r$ was used to determine the correlation. The study found that work motivation andjob satisfaction of basic public schools in Metro Vigan and Caoayan is very high and there was no correlation between work motivation of both gender and job satisfaction. It also found that there was no difference between job satisfaction of male and female teachers and as whole, there was no difference between work motivation of both genders but taking it singly, there was a difference on work motivation of both genders in terms of integrated regulation.
\end{abstract}

Keywords-Gender differences, work motivation, job satisfaction.

\section{INTRODUCTION/ RATIONALE}

Motivation and satisfaction are two most important factors that a manager needs to monitor among his/her employees. Improving the level of motivation of employees will help them improve job satisfaction and consequently organizational goals can be achieved. Worker's motivation and work satisfaction are interrelated. Both has causal relationship because one can affect the other. Thus, improving motivation of employees causes job satisfaction. Most of the studies on work motivation and job satisfaction tend to generalize without distinction between male and female. However, the current study argues that male and female are two different kinds of human being. Their differences are not just in terms of physical structure or in terms of gender, but most importantly, its difference lies on how the brain works which affect how they work and their perception about the work. Male brain and female brain functioning are not the same and such differences can affect the way how they perform their job, and the way how they react to problems in their work.

It is also common that work motivation has been treated as a unitary concept without the distinction between intrinsic and extrinsic motivation (Deci and Ryan, 1971, 1975) and the extrinsic motivation is always treated as a unitary concept without the classification of external, introjected, identified and integrated regulation (Ryan \& Deci, 2002). Therefore, the current study classifies the male and female work motivation and job satisfaction.

Recognizing the importance of work motivation and job satisfaction to the attainment of objectives of any industries which includes the schools, therefore the current study is conducted to determine the level of motivation and its differences among male and female teachers and job satisfaction of male and female teachers/employees of Basic Public Education in Metro Vigan and Caoayan in Ilocos Sur, Philippines.

The Significance of the Study

The study is intended to help the administrators of these schools to identify the factors that motivate employees, both female and male and improve factors that affect motivation of both genders. It is also intended to revise the existing 
policies of the schools that tend to treat the employees the same and generalize the compensation and benefits given to all employees.

\section{Theoretical Framework \\ Gender Differences Theories}

Before going into determining work motivation and job satisfaction in women and men, it would be better to explain the gender differences because gender differences could explain the difference of work motivation and job satisfaction. There have been studies on motivation and job satisfaction but those studies treat motivation and job satisfaction as unitary concept applied to both gender. They have not explored into the differences of motivation and job satisfaction of both gender. The current study would like to see the differences because both genders are not the same in terms of how their brain works. To prepare us understand the difference between work motivation and job satisfaction of both genders, we select theories and researches that explain the gender differences, how the brain of man and woman works and how they affect the work motivation and job satisfaction of both.

We have been talking about gender equality in all forms, not only in any woks, leadership, politics but even in sports but gender equality in this regard does not erase the fact about gender differences, that one is male and the other is female. Such differences bring with it differences in both aspects such as physical and mental differences (Romanes, 1887, Dovey, 2014) and such differences started in the womb. It is already programmed within the DNA from the moment of conception. Since then male's and female's physical and mental structure are different (Miller, 2007, pp. 3-9). Miller (2007) argued that physical differences are not just about the difference of sexual organs but there are many examples of differences, such as, physical structures. Miller (2007) pointed out that the average men is taller and heavier than average women, man has more body hair than woman do, especially on the chest and extremities, women is more sensitive to sound than men, men have larger hearts and lungs, and their higher levels of testosterone cause them to produce greater amounts of red blood cells. There are also differences in intake and delivery of oxygen. Such differences translate into some aspects of performance, for example, when a man is jogging, he needs about $50 \%$ of his capacity, while a woman will need to work at over $70 \%$ of her capacity to keep up with the man. In terms of skin, men's skin has more collagen and sebum, which makes it thicker and oilier than women's skin. Differences are also found in the amount of hormones. Men and women have different levels of certain hormones. Men have a higher concentration of androgens such as testosterone, while women have a higher concentration of estrogens, etc (Miller, 2007). These differences definitely cause differences in many aspects of life including work motivation and job satisfaction.

However, the focus of our attention of differences in man and woman is not about physical differences only but mental differences. Mental differences originate in brain differences which cause how the brains works. (Romanes, 1887, Cool, n.d \& Jantz, 2014) and such differences cause the difference between men and women in terms of work performance. As Cool (n.d) and Jantz (2014) argued that such differences can explain the reason why males outperform females on certain mental skills test, while females have the edge in others. Romanes (1887) pointed out that brain weight of women is about five ounces less than that of men, while Cool (n.d) pointed out that male brains are about $10 \%$ larger than female brains. Regardless of who is right in terms of the brain size, both point out the differences. Both, Romanes (2007) and Cool (n.d) have different explanations about the implication of the differences of brain size. Romanes (2007) argued that such differences cause male to have higher intellectual power than female. However, Cool (n.d), based on his research argued otherwise that there have been no differences in men and women's IQs. Cool (n.d) explained that bigger does not mean that man is more intelligent than a woman. Such explanation is supported by the finding of Miller (2007). Miller (2007, pp. 3-9) on his research found that there is no significant difference in the average intelligence level of men and women. Men and women have their edge and one is not better that the other. He elaborated further that women have more connections going left and right across the two halves of the brain. Such brain structure explains the edge of women over men that women have the capability to pull information together from different sources and drawing conclu sions and at the same time women have better intuition than men. The left half of the brain then takes care of critical thinking while the right half of the brain takes care of the emotion.

According to Jantz (2014) such differences are more on processing, and chemistry. He explains that male brains utilize nearly seven times more gray matter or thinking matter (Cool, n.d), while female brains utilize nearly ten times more white matter. Gray matter is the information and action processing centers. In Jantz' view, such differences could explain that once man engages in a certain activity or game, he does not show much sensitivity to other people and the surroundings. The other side is white matter. White matter explains the networking of the brain. It is the networking grid that connects the brain's gray matter and other processing 
centers with one another. This explains that women are faster in terms of shifting between two tasks than men. In terms of chemistry Jantz (2014) explains that both men and women have the same neurochemicals, but they work differently. Jantz (2014) identified four kinds of neurochemicals and these are serotonin which helps us sit still, testosterone, our sex and aggression chemicals, estrogen, a female growth and reproductive chemical and oxytocin, a bonding - relationship chemical. According to Jantz (2014), because of the differences in processing chemicals, male tends to be less inclined to sit long as female and tend to be physically impulsive and aggressive. Further, male is fast acting and therefore male is prone to risks, while females express their emotions more readily and experience a greater intensity of emotion (Miller, 2007, pp. 3-9).

\section{Work Motivation Theory}

According to Hartzell (n.d), motivation refers to the psychological processes that stimulate excitement and persistence of voluntary actions aimed at some goals. No body moves into action if nothing motivates him /her to go into action. It is the reason why a person works hard, and others do not. Those motivations can be physiological and psychological needs. It directs the behavior of the person. As Joday, et.al (2013) explained that motivation is viewed as one of the most important factors that inspire an individual person to move into action.

Maslow had structured the human needs into five categories which fall within physiological, sociological and psychological. These needs motivate a person to go into action. He summarized those human needs into what we call Maslow's hierarchy of needs (1954). It is generally accepted as a scheme to classify human motives (Pardee, 1990). He structured the needs into five stages that one must go through and these are physiology needs, safety needs, social needs, self-esteem or achievement and self-actualization. Physiological needs refer to the basic needs such as air, water, food, sleep, sex, etc. When these basic needs are not fulfilled, a person can get sick or die. After fulfilling the basic needs, the next level is safety needs which refers to stability and consistency in a chaotic world. All human beings need safety or security. Only when the security needs are fulfilled, then one can go to the next level which is social needs. This is the need in which people want to be loved and to belong. It is a fact that each human person has a strong desire to love and to be loved, to be accepted by other groups, to be associated with clubs, professional groups, and even churches and religious groups, etc. Next after these needs, a pers on moves to a higher level of needs which is self-esteem. This need is achieved when a person is given recognition because of his/her achievement. A person wants to achieve something because he/she wants to be recognized by other people and by achieving the recognition, the person can achieve self-esteem. And the last level of Maslow hierarchy needs is self-actualization. At this level a person's motivation to works is to realize his full potential. Usually, this can include the pursuit of knowledge, peace, esthetic experiences, self-fulfillment, oneness with God, nirvana, enlightenment etc. (Hartzell, n.d).

If Maslow pointed out hierarchy of needs as source of motivation, Herzberg, et.al (1959) presented a two-factor theory to explain the human motivation. This theory is also known as Herzberg's motivation-hygiene theory and dualfactor theory. This theory argues that there are factors in the workplace that causes satisfaction and dissatisfaction. The presence and the absence of these factors can either cause satisfaction or dissatisfaction. These factors motivate people to work. He identified motivators such as challenging work, recognition, and responsibility and hygiene factors such as status, job security, salary, fringe benefits. According to him these factors (hygiene factors), if they are present, may not motivate but if they are absent resulting in demotivation. Therefore, Herzberg argues that job satisfaction and dissatisfaction are the product of motivating factors or satisfiers and hygiene factors or dissatisfiers. Satisfiers may include company policy, supervision, working conditions, interpersonal relations, salary, status, job security, and personal life (Pardee, 1990).

Another figure that we cannot just ignore in the motivation theory is Alderfer (1969). He presented ERG theory and this theory simplifies the hierarchy needs theory of Maslow. ERG theory stands for existence, relatedness and growth needs as a source of motivation. The existence needs are related to the basic physiological and safety needs of Maslow which are concerned with providing the basic material needs required for human existence such, air, water, food, sleep, sex, and security or safety needs. While the relatedness needs are related to the social needs of Maslow which is the desire people to belong to the society, or the group and the desire to be love and to be loved. Finally, Alderfer identifies growth need as an intrinsic desire for personal development. Growth need is the intrinsic component of Maslow's theory such as esteem need and the self-actualization needs. According to Alderfer when the higher needs (growth need) cannot be achieved, a person regresses or going back to satisfy the lower needs (Existence and relatedness). For example, if selfactualization or self-esteem cannot be achieved, then individuals go back and will invest more effort in the 
relatedness need or existence need in the hopes of achieving the higher need.

If Alderfer synthesizes the theory of Maslow into three components of needs such as existence, relatedness and growth (ERG), while, McClelland (1961,1998) identifies only three kinds of needs and they are need for achievement, need for affiliation and need for power. McClelland argues that everyone has the urge deep within that pushes or motivates someone to excel, to achieve something within the standards or beyond the standards. Often time those who are called achievers tend to avoid low-risk because they want to be challenged and at the same time, they avoid high-risk venture because they want to be sure that they will achieve their goals. Therefore, high nAch individuals (achievers) prefer works that have moderate probability of success. While those who belong to nAff (need for affiliation), they prefer harmonious working relationship with other people and these types of people find ways how to be accepted by other groups. Persons belong to the group avoids conflict and follow the established norms and they prefer works that provide significant personal interactions. Finally, those who have need for power refers. This refers to persons who have the desires to control and direct others. People who belong to this category want to be given position through which they can control other people.

The above theories of motivation remind the managers or leadership that people have different needs and therefore, people who have different needs are also motivated differently. For example, for those who have high nAch needs challenging tasks and frequent feedbacks and the ones who have high nAff needs for cooperative environment and lastly those who have high need for power look for opportunity to manage others or to supervise others

\section{Self-Determination Theory (SDT)}

Self-determination theory argues that human beings have natural tendencies to work according to their individual interest. Children usually perform activities according to their inner direction. They perform activities for the sake of the enjoyment found in the activity. However, once the person grows up in the society, he/she is no longer acting according to his/her inner direction as he/she wishes but acting according to the demand of the society. External demands motivate him/her to perform certain job or activities. Therefore, Ryan and Deci (2002) argued that although psychological growth and integration tendencies are natural, but they are susceptible to social and environmental conditions which may support propensities for self-determination or disrupt them.
SDT motivation theory applies to activities that people find interesting, challenging and aesthetically pleasing. These are activities that people perform naturally without the external force. Intrinsically motivated persons perform activities for its own sake because one finds the activity inherently interesting and satisfying. However, it cannot be denied that not all activities are performed intrinsically motivated, there are many activities or work performed because of external motivation in which a person does the activity for a certain instrumental reason (Ryan \& Deci, 2002).

Previous motivation theories (Maslow, Herzberg, Alderfer, and McClelland) presented above are now classified into extrinsic and intrinsic motivation. However, simple dichotomy between intrinsic and extrinsic motivation made the theory difficult to apply to work settings. Classifying extrinsic motivation into different types lead to SelfDetermination Theory. Self-Determination Theory is a theory of work motivation. Under SDT, motivation is not treated as singular construct but divided motivation into intrinsic and extrinsic motivation with its classification (Gagne \& Deci, 2005, pp. 331-362). Intrinsic motivation is defined as the inherent desire to seek challenges, to work and perform activities on one's capacities and finds enjoyment in such activity (Deci and Ryan, 2000). While extrinsic motivation is defined as the absence of inner excitement and find excitement in performing the job but perform the job to attain separable outcome. For example, employees do their job, not because they find enjoyment in doing their job but because of external pressures (Ryan and Deci, 2000). Within the SDT, OIT (Organismic Integration Theory), a sub-theory of SDT, classified extrinsic motivation into external regulation, introjected regulation, identified regulation, and integrated regulation. External regulation refers to motivation that is externally controlled and their actions have external locus of causality (deCharms, 1968). Introjected regulation means taking regulation but not fully accepting it as one's own. A person performs the job to avoid feeling guilty. He/she performs the job to maintain feeling of worth (, William, Grow, Freeman, Ryan \& Deci, 1996). While identified regulation reflects a conscious valuing of a behavioral goal or regulation in which a pers on accepted that such action is important. Finally, integrated regulation means a person has evaluated certain action to be in congruence with their own personal values.

\section{Job Satisfaction}

Job satisfaction measures how satisfied a person is in his/her job. It is a feeling that a person has when he/she has completed a job. Having done the job well is what brings satisfaction to the person. The pleasure or joy of doing a job 
is what is called as job satisfaction. It is the joy or the pleasure of working and it is the sense of accomplishment after having done a job-well done. Since it is a feeling, not all employees will have the same feeling, even though they are doing the same job and within the same environment. There might be few who get job satisfaction and there are also some who might not be satisfied. This is because satisfaction is not just caused by a single factor, but it is the output of different factors such as training and development, supervision, compensation and benefits and working relationship.

\section{Training and Development}

Training and development are defined as organization's effort to improve employees' performance. It can also be defined as educational development process of employees to sharpen their skills, concepts and improve their knowledge and attitude to enhance their performance (Qureshi, 2016). Training and development are always based on the organizational assessment. Through assessment, the organization identifies performance problems and determines the causes of those problems and then decides on what training and development are needed to improve the performance. Therefore, it is necessary for the individual development and employees' progress, which motivates him to work for the organization apart from just money. Training and development are one way of responding to the changes and development in the market place or market environment (Yip, 2018). Landy (1985) defined job training as an organized activity from the management to improve job knowledge, skills and to modify the attitudes and social behavior of its employees to be cons is tent with the objectives of the organization and as demanded by the job" (p. 306). Training is systematic development of the knowledge, skills, and expertise required by a person to effectively perform a given task or job (Patrick, 2000)

\section{Supervision}

Business Dictionary defines supervision as" the action of overseeing and managing employees in the workplace". It is also understood as guiding employees with specific instructions on the job to be done, monitoring the development of the work, reviewing the accomplishment of the work and holding them accountable for specific results (Jordan, 2017). Supervision is a day to day's work and therefore such supervision should be based on the es tablished performance indicators agreed beforehand that reflect the critical success factors of an organization (StudyMode Research, 2013). Supervis or oversees the work of employees and establish controls to improve the work as well as the worker based on the pre-established standards of performance. It is the immediate guidance given to employees in the performance of their work. It involves giving feedbacks to employees to ensure the quality of their work and to sustain or to improve quality of work output. It is the supervisor who provides parameters of the work, performance reviews, and help employees avoid, identify, and solve problems (Kleiman, 2004). It has been also argued that that perceived supervis or leadership style may contribute to employee well-being, job satisfaction and organizational commitment.

\section{Compensation and benefits}

Compensation and benefits are tangible and intangible rewards such as recognition, work-life and development. It can also be defined as all the rewards earned by employees in return for their labor. This includes direct financial rewards in terms of salary, bonuses, commissions provided at a regular basis. This may also be called guaranteed pay. Indirect financial compensation includes financial rewards that are not included in the financial compensation but form part of the social contract between the employer and the employees such as benefits, leaves, retirement plans, education, and employees' services. Nonfinancial compensation may include career development, and promotion, opportunities for recognition, and work environment conditions. This may be called benefits, (hrcouncil.ca, n.d).

The compensation and benefits are important because employees are not willing to work hard for the company when they feel that they are not taken care of. It is through compensation that employees are recognized. Compensation ensures that hard-working employees are rewarded fairly. This will satisfy and motivate them to contribute more to the company and sustain their performance. Good compensation benefits do not only aim at retaining employees in the company, but it is also important to attract the best talent to the company. For many people, the reason why they apply to a certain company is salary and incentive packages. Good compensation and benefits tend to attract best talents (allabout careers, n.d).

\section{Working relationship}

Working relationship refers to employer-employees and employee-employee relationship in the workplace. Maintaining good relationship in the workplace is very important for the attainment of the goals. It cannot be denied that employees are working for the business and the business needs the employees to carry out its work. In such relationship, there must be mutual interactions and mutual respect. Whatever kind of relationship allowed by the business, harmonious relationship is necessary. Both are mutually dependent on each other in which employer relies 
on the employees to carry out the work and employees rely on the employer for the direction, resources and compensation and benefits. Thus, it is crucially important for the employer to build good relationship, while at the same time setting the boundaries are important to know the limits (Schreiner, 2018). Strong relationship between employer and employee is important because it is the key to ultimate success of the organization. It has been argued that if there is a strong relationship in the workplace, employees' productivity will improve, reduce conflicts and loyalty to the company will improve (O’Brien, 2014). While maintaining good relationship with the employer is important, it is likewise important to maintain good relationship with coworkers. It is important because by nature employees are not only individual being, but they are social being and they need other people to talk to, to share ideas with and to share their happiness and sorrows. It is argued that an isolated environment demotivates an individual and spreads negativity around (Yip, 2018).

\section{RELATED STUDIES}

\section{On Work Motivation and Job satisfaction}

Schmidt (2007) conducted a study on "The Relationship between Satisfaction with Workplace Training and Overall Job Satisfaction". The study focused on the relationship between satisfaction with employer-provided workplace training and overall job satisfaction of customer contact representatives. The study concluded that there is a significant relationship between job training satisfaction and overall job satisfaction. All variables of the study such as time spent in training, training methodologies and the content of training were all correlated to job training satisfaction. This finding is confirmed by other studies. Tella and Ayeni (2007) also pointed out the same result that there is a relationship between work place training and job satis faction. Workplace training improve work motivation which contributes to job satisfaction. Such finding was also supported by Brown and Shepherd, (1997) who reported that motivation improves workers' performance and job satisfaction. Those findings are similar with the finding of Danish (2010), as he pointed out that certain motivational factors contribute to the prediction of job satisfaction. As to the motivational factors affecting job satisfaction, the study of Halici (2012) argued that employees give more importance to behavioral approaches.

Related to motivational factors, there are financial and nonfinancial rewards that can motivate employees to work. Motivational factors cannot be generalized. In other words, money or salary may not be the single factor causing motivation and job satisfaction of employees but there are other non-financial factors that affect motivation and job satisfaction as pointed out by Bazan (2009) that employees' level of job satisfaction was not higher when motivated by rewards and pay. He pointed out that teachers do not have the highest paying jobs and he found that pay did not appear to be an important factor to most of the staff and teachers. Such finding strengthens the idea that there are non-financial rewards that affect job satisfaction as indicated by the finding of Tausif (2012) that non-financial rewards are the strong determinant of job satisfaction for the employees. Financial rewards and job satisfaction may not be generally applied to all people. His finding showed that the satisfaction increases with the increase in age. The old employees are more satisfied with job rewards than young employees. This is again emphasized by the finding of Abdullah, Teng and Bustaman (2014) on the financial and non-financial factors of motivation. Their study concluded that that non-financial rewards are positively and significantly associated with job satisfaction. However, among those rewards, it is still recognized that financial rewards have the strongest impact on job satisfaction than non-financial rewards.

The above finding may support the argument that not every place, not everyone, not every age or not every nation have the same factor of motivation. As shown, it is depending on the level of economic conditions. Countries that are poor may need financial support to motivate them to work as compared to wealthy nation as it was pointed out by the study of Aziri (2011, pp.77-86) that on certain places, financial compensation has a great impact on the overall job satisfaction of employees. This was proven by the study of Mustapha (2013) on the influence of financial reward on job satisfaction among academic staff of Public Universities in Kelantan, Malaysia. It manifested that there was a positive relationship between financial reward and job satisfaction. It was also confirmed by the study of Mehta in Pakistan that the increase in monetary rewards has affected positively on the employee performance and job satisfaction. However, the study still acknowledges that such impact may be different from one individual to other individual persons and from one place to other places. Some people, some countries are highly motivated by things other than financial rewards (Essays, 2013).

In short, there are many factors affecting the motivation and job satisfaction of employees and those factors are ranged from financial and non-financial rewards. Salaries, benefits and bonuses are still considered the most important variable for employee satisfaction (Singh \& Jain, 2013, pp. 105-111). There are also many non-financial factors that change 
employee's performance such as worker and employer relationship, working conditions, job security, training and opportunity of development, and overall rewarding policies of the company (Priya, Eshwar, 2014). Whatever kind of rewards, the lesson is that rewards affect the motivation and job satisfaction of employees as emphasized by the study of Jehanzed, et.al (2012) that rewards have positive significance on motivation and motivation is positively related to the job satisfaction. Overall, rewards have a positive significant effect on job satisfaction.

\section{On Gender Differences and Job satisfaction}

ESSAYS (2015) went through review of literature to determine the gender differences in work motivation and job satisfaction. Based on the result of the literature review, it concluded that gender differences in job satisfaction has been found to have no conclusive evidence about the levels of satisfaction among men and women. This finding was already pointed by the previous study on gender differences on job satisfaction. Mabekoje (2009) had conducted a study on gender differences on job satisfaction among secondary schoolteachers in Nigeria and the study concluded that there are no gender differences existed in all the dimensions of job satisfaction as well as the overall job satisfaction of teachers. Azim, Haque, and Chowdhury (2013) supports the similar finding. They conducted a study on gender, marital status and job satisfaction among employees in Bangladesh and their study found that there is no statistically significant evidence is observed indicating differences in job satisfaction level between 'male' and 'female' or between 'married' and 'unmarried'.

However, these findings may not be true everywhere. Kim (2005) studied on the gender differences in job satisfaction among public employees in Seoul, Korea and his study revealed that women are more satisfied with their jobs than men. Among demographic variables gender was the only significant predictor of job satisfaction; women emphasized intrinsic rewards, whereas men emphasized extrinsic rewards. This finding is supported by the previous study of Rohrbeck (1988) on the relationship between gender and job- satisfaction in high school students employed part time. The study concluded that gender was found to be related significantly, but to a small degree, to job satisfaction. Such finding further strengthened the previous idea that female and male have different reasons to work. Females seemed to be more driven by intrinsic motivation that they work to learn new skills or gain work experience more than males were as emphasized by the study of Clark (1997). But in the context of Pakistan, male employees are more satisfied with their jobs as compared to female employees (Fatima, Iqbal, Akhwand \& Suleman, 2015). This could be explained by the reasons why female and male go into work as Erat, et.al (2012) argued that career motivation has a positive correlation with organizational commitment and job satisfaction.

Those previous studies measured gender differences and job satisfaction, and there were no common agreements on the relationship between gender and job satisfaction. Further, they have not measured gender differences motivation and jobs satisfaction. The current study argues that gender and motivational differences may appear among men and women because it assumes that job satisfaction comes after motivation. Motivation level affects job satisfaction and motivation and satisfaction may vary from male to female workers (Burks, 2018). Therefore, motivation needs to be measured and to what extent it affects job satisfaction.

\section{Conceptual Framework}

Independent variables

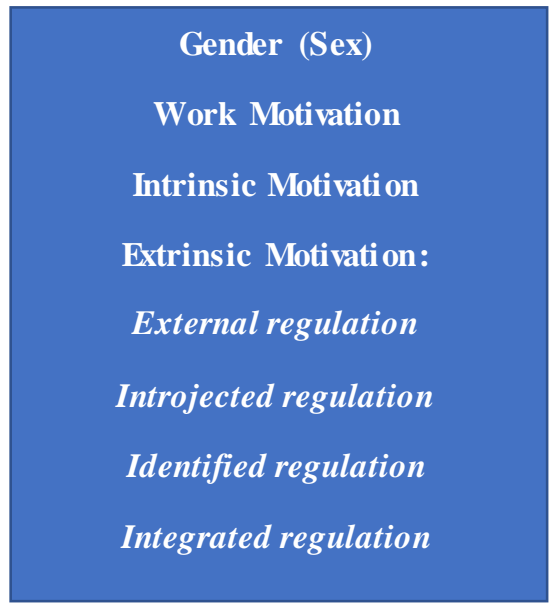

Dependent Variables

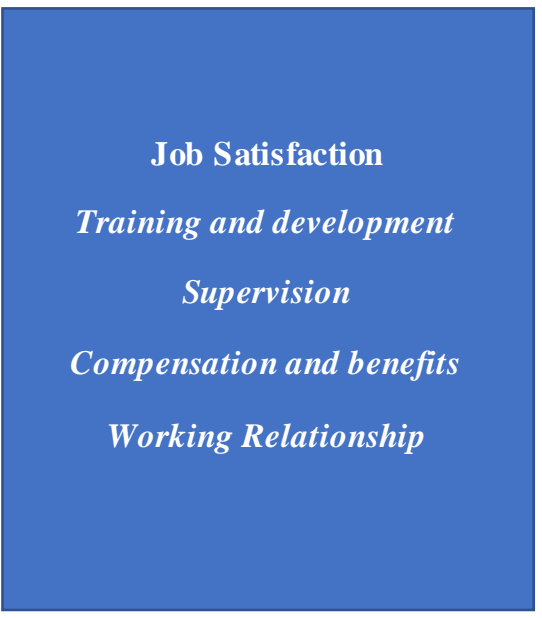


Fig.1: conceptual framework reflects the relationship between work motivation of male and female employees and job satisfaction.

\section{STATEMENT OF THE PROBLEM}

The study would like to determine the effect of work motivation of male and female employees of Public Basic Education in Metro Vigan, Philippines, specifically it seeks to answer the following questions:

1. What is the sex (gender) of employees of Public Basic Education in Metro Vigan and Caoayan, Ilocos Sur, Philippines?

2. What is the intrinsic motivation of male and female employees of Public Basic Education of Metro Vigan and Caoayan, Ilocos Sur, Philippines?

3. What is the extrinsic motivation of male and female employees of Public Basic Education of Metro Vigan and Caoayan, Ilocos Sur, Philippines in terms of:

a. External regulation

b. Introjected regulation

c. Identified Regulation

d. Integrated regulation?

4. What is the job satisfaction of male and female employees of Public Basic Education of Metro Vigan and Caoayan, Ilocos Sur, Philippines in terms of

a. Training and Development

b. Supervision

c. Compensation and Benefits

d. Working relationship?

5. Is there a relationship between work motivation of male and female employees of Public Education of Metro Vigan and Caoayan, Ilocos Sur, Philippines and their job satisfaction?

6. Is there a difference between motivation of male and female employees?

7. Is there a difference between job satisfaction of male and female employees?

\section{Assumption of the Study}

The study assumes that the questionnaires of the study are valid and work motivation and job satisfaction of male and female employees can be measured. The answers of the questions are honest.

\section{Hypothesis}

Kim (2005) found that there is a significant difference between job satisfaction of male and female employees and therefore the hypothesis of the study will be:

1. There is a positive relationship between work motivation and job satisfaction,
2. There is a gender difference on work motivation and job satisfaction.

\section{Scope and Delimitation of the Study}

The study is only to measure the relationship between work motivation of male and female employees of Public Basic Education of Metro Vigan and Caoayan, Ilocos Sur, Philippines and their job satisfaction. The study covers only to measure the relationship between sex, intrinsic motivation, extrinsic motivation and job satisfaction.

\section{METHODOLOGY}

To carry out the study, an appropriate research methodology was utilized. Therefore, this part discusses research design, data gathering instruments, population, locale of the study, data gathering procedures and statistical treatment of data.

\section{Research Design}

Since the study is a quantitative research, thus, the study used descriptive correlational method research design and fact-finding inquiry to determine the level of work motivation and job satisfaction of male and female employees. It describes what is found in the data. It concerned with the data collected on a research sample. It describes the profiles, frequency distribution, characteristics of people, situations, phenomena or relationships of variables (Ariola, 2006). It merely describes "what is" about the data. Or it describes relationships that exist, practices that prevail, beliefs, processes that are going on; effects that are being felt or trends that are developing (Best \& Kahn, 1993).

\section{Locale of the Study}

The locale of the study was Public Basic Education within Metro Vigan and Caoayan, in Ilocos Sur.

Population

The population of the study was composed of all employees of Public Basic Education within Metro Vigan and Caoayan, Ilocos Sur. The total number of employees are limited and therefore totalenumeration or 263 employees are taken as the sampling design of the study.

\section{Data Gathering instruments}

The study utilized questionnaires. For the intrinsic and extrinsic motivation, the questionnaires were adapted from the study of Blanchard, Taylor, Pelletier and Villeneuve (2009). While questionnaires on job satisfaction were made by the researcher and validated by the expert on the subject matter. 


\section{Data Gathering Procedures}

In the process of data gathering, the researcher sent letters to the Superintendent of Basic Public Education of Ilocos Sur Province and the different Principals or heads of the schools. The researcher personally met the Superintendent and the Principals and employees and requested them to answer the questionnaires.

The retrieval of questionnaires was arranged between the Principals and the researcher with the help of employees of different schools.

\section{Statistical Treatment of Data}

In consistent with the study as descriptive research, therefore descriptive statistics is used. The weighted mean was used to measure the level of motivation and the Pears on $r$ were used to measure the strength of correlation between work motivation and job satisfaction of employees. T-test was used to measure the difference between motivation and job satisfaction of male and female employees.

The following ranges of values with their descriptive interpretation will be used:

$\begin{array}{ccc}\text { Statistical Range } & \text { Descriptive Interpretation } & \text { Overall Descriptive Rating } \\ 4.21-5.00 & \text { Very true (Very High) } & \text { Very satisfied (Very High) } \\ 3.41-4.20 & \text { True (High) } & \text { Satisfied (High) } \\ 2.61-3.40 & \text { Somewhat true (Moderate) } & \text { Somewhat satisfied (Moderate) } \\ 1.81-2.60 & \text { Not true (Low) } & \text { Dissatisfied (Low) } \\ 1.00-1.80 & \text { very untrue (Very Low) } & \text { Very dissatisfied (very Low) }\end{array}$

\section{Findings}

The finding of the study is presented according to the statement of the problems of the study.

Problem 1: What is the sex (gender) of employees of Public Basic Education in Metro Vigan and Caoayan, Ilocos Sur, Philippines?

Table.1: The gender of Employees of Public Basic Education in Metro Vigan and Caoayan.

\begin{tabular}{|l|l|l|l|l|}
\hline Gender & Male & \% & Female & $\%$ \\
\hline & 41 & $15.59 \%$ & 222 & $84.41 \%$ \\
\hline
\end{tabular}

Based on the data collected, it shows that there are 41 or $15.59 \%$ male and 222 or 84.41 female employees. It means that majority of the teaching force of Public Basic Education in Metro Vigan and Caoayan is female.

Problem 2: What is the intrinsic motivation of male and female employees of Public Basic Education of Metro Vigan and Caoayan, Ilocos Sur, Philippines?

Table.2: Intrinsic Motivation

Intrinsic motivation of male and female employees

\begin{tabular}{|l|l|l|l|l|l|l|}
\hline & Male & & Female & & As a whole & \\
\hline $\begin{array}{l}\text { 1. Because I derive much pleasure from learning new } \\
\text { things in my job }\end{array}$ & 4.41 & VH & 4.46 & VH & 4.44 & DR \\
\hline $\begin{array}{l}\text { 2. for the satisfaction I experience from taking on } \\
\text { interesting challenges }\end{array}$ & 4.20 & H & 4.40 & VH & 4.30 & VH \\
\hline $\begin{array}{l}\text { 3. For the satisfaction I experience when I am } \\
\text { successful at doing difficult task }\end{array}$ & 4.34 & VH & 4.48 & VH & 4.41 & VH \\
\hline Overall & 4.32 & VH & 4.45 & VH & 4.39 & VH \\
\hline
\end{tabular}

Legend

4.21-5.00

$3.41-4.20$

$2.61-3.40$

$1.81-2.60$

$1.00-1.80$
Very true (Very High) (VH)

True (High) (H)

Somewhat true (Moderate) (M)

Not true (Low) ( L)

very untrue (veryLow) (VL) 
As it is shown on the data, it reveals that overall basic publicschool teachers' intrinsic motivation is 4.32 for male and 4.45 for female which are interpreted as very true or very high. From its mean rating, it shows that women are higher in term of intrinsic motivation than man. As a whole, intrinsic motivation of all public-school teachers in Metro Vigan and Caoayan is 4.39 which is considered very true or very high. It means that basic public-school teachers in Metro Vigan and Caoayan are doing their job because they want to learn new job, they love new challenges and they get satisfaction from taking difficult task. They are doing it for pleasure in taking the job. Taking individual items, it shows that women have higher mean rating in all questions than man. Man has lower rating (4.20) than women (4.40) in terms of experiencing satisfaction from taking on interesting challenges.

Problem3: What is the extrinsic motivation of male and female employees of Public Basic Education of Metro Vigan and Caoayan, Ilocos Sur, Philippines in terms of external regulation?

Table 3a. External regulation

\begin{tabular}{|l|l|l|l|l|l|l|}
\hline & Male & & Female & & As a whole & \\
\hline External regulation & $\mathrm{X}$ & $\mathrm{DR}$ & $\mathrm{X}$ & $\mathrm{DR}$ & $\mathrm{X}$ & $\mathrm{DR}$ \\
\hline 1. For the income it provides me & 4.37 & $\mathrm{VH}$ & 4.30 & $\mathrm{VH}$ & 4.34 & $\mathrm{VH}$ \\
\hline 2. Because it allows me to earn money & 4.27 & $\mathrm{VH}$ & 4.30 & $\mathrm{VH}$ & 4.29 & VH \\
\hline 3. Because this type of work provides me with security & 3.93 & $\mathrm{H}$ & 3.87 & $\mathrm{H}$ & 3.90 & $\mathrm{H}$ \\
\hline Overall & 4.19 & $\mathrm{H}$ & 4.20 & $\mathrm{H}$ & 4.20 & $\mathrm{H}$ \\
\hline
\end{tabular}

Legend

4.21-5.00

$3.41-4.20$

$2.61-3.40$

$1.81-2.60$

$1.00-1.80$
Very true (Very High)

True (High)

Somewhat true (Moderate)

Not true (low)

very untrue (very Low)
Comparing to intrinsic motivation, extrinsic motivation in terms of external regulation is lower than intrinsic motivation. As it is revealed on the table of computation, it shows that overall extrinsic motivation, in terms of external regulation of basic-public school teachers is 4.19 for male and 4.20 for female which are all interpreted as true or high. regulation of basic public-school teachers is 4.20 which is considered as true or high. Such rating means that basic public-school teachers' extrinsic motivation in terms of external regulation is high but not very high. It means further that they are doing their job because of external pressures such as for money, and security. As a whole, extrinsic motivation in terms of external

Table $3 b$. Introjected regulation

\begin{tabular}{|l|l|l|l|l|l|}
\hline & Male & & Female & As a whole & \\
\hline Introjected regulation & $\mathrm{X}$ & $\mathrm{DR}$ & $\mathrm{X}$ & $\mathrm{DR}$ & $\mathrm{X}$ \\
\hline $\begin{array}{l}\text { 1. Because I want to succeed at this job, if not, I would be very } \\
\text { ashamed of myself }\end{array}$ & 3.73 & $\mathrm{H}$ & 4.06 & $\mathrm{H}$ & 3.90 \\
\hline $\begin{array}{l}\text { 2. Because I want to be very good at this work, otherwise, I } \\
\text { would be very disappointed }\end{array}$ & 3.85 & $\mathrm{H}$ & 4.05 & $\mathrm{H}$ & 3.95 \\
\hline 3. Because I want to be a winner in life & 4.10 & $\mathrm{H}$ & 4.01 & $\mathrm{H}$ & 4.06 \\
\hline Overall & 3.89 & $\mathrm{H}$ & 4.04 & $\mathrm{H}$ & 3.97 \\
\hline
\end{tabular}

Legend

4.21-5.00

$3.41-4.20$

$2.61-3.40$

$1.81-2.60$

$1.00-1.80$
Very true (Very high)

True (High)

Somewhat true (Moderate)

Not true (Low)

very untrue (very Low) 
As it is presented on the table, the data reveals that overall, introjected regulation of basic public-school teachers is 3.89 for male and 4.04 for female which all are considered as true or high. Taken them as a whole, it shows that extrinsic motivation in terms of introjected regulation is 3.97 which is interpreted as true or high. It means that they are doing their job because they would be ashamed of themselves if they fail (3.73, 4.06), they would be very disappointed of themselves if they are not good at their work $(3.85,4.05)$ and they would like to be a winner in their life $(4.10,4.04)$. In such case, they are doing their job well but not fully their own yet. External circumstance is still part of the influencing factor.

Table 3c. Identified Regulation

\begin{tabular}{|l|l|l|l|l|l|l|}
\hline & Male & & Female & & As a whole & \\
\hline Identified regulation & $\mathrm{X}$ & $\mathrm{DR}$ & $\mathrm{X}$ & $\mathrm{DR}$ & $\mathrm{X}$ & $\mathrm{DR}$ \\
\hline $\begin{array}{l}\text { 1. Because this is the type of work, I chose to do to attain certain } \\
\text { lifestyle }\end{array}$ & 3.95 & $\mathrm{H}$ & 4.05 & $\mathrm{H}$ & 4.00 & $\mathrm{H}$ \\
\hline 2. Because I chose this work to attain my career goals & 4.15 & $\mathrm{H}$ & 4.31 & $\mathrm{VH}$ & 4.23 & $\mathrm{VH}$ \\
\hline $\begin{array}{l}\text { 3. Because it is the type of work, I have chosen to attain certain } \\
\text { important objectives }\end{array}$ & 4.24 & $\mathrm{VH}$ & 4.24 & $\mathrm{VH}$ & 4.24 & $\mathrm{VH}$ \\
\hline Overall & 4.11 & $\mathrm{H}$ & 4.20 & $\mathrm{H}$ & 4.16 & $\mathrm{H}$ \\
\hline
\end{tabular}

Legend

4.21-5.00

$3.41-4.20$

$2.61-3.40$

$1.81-2.60$

$1.00-1.80$

\author{
Very true (Very High) \\ True (High) \\ Somewhat true (Moderate) \\ Not true (Low) \\ very untrue (Very Low)
}

As gleaned from the data, it appears that overall, extrinsic motivation of basic public-school teachers in terms of identified regulation is 4.11 for male and 4.20 for female which is interpreted as true or high. Taking it as a whole, it reveals that extrinsic motivation in terms of identified regulation is 4.16 which is considered true or high. It means that teachers are doing their job because they believe that through such work they can attain certain lifestyle, career goals or to attain certain objectives. They have chosen teaching career because they value it important for their life and their objectives.

Table $3 d$. Integrated regulation?

\begin{tabular}{|l|l|l|l|l|l|l|}
\hline & Male & & Female & & As a whole & \\
\hline Integrated regulation & $\mathrm{X}$ & $\mathrm{DR}$ & $\mathrm{X}$ & $\mathrm{DR}$ & $\mathrm{X}$ & DR \\
\hline 1. Because it has become a fundamental part of who I am & 4.24 & $\mathrm{VH}$ & 4.42 & $\mathrm{VH}$ & 4.33 & VH \\
\hline $\begin{array}{l}\text { 2. Because it is part of the way in which I have chosen to live } \\
\text { my life }\end{array}$ & 4.07 & $\mathrm{H}$ & 4.43 & $\mathrm{VH}$ & 4.25 & VH \\
\hline 3. Because this job is part of my life & 4.34 & $\mathrm{VH}$ & 4.62 & $\mathrm{VH}$ & 4.48 & VH \\
\hline Overall & 4.22 & $\mathrm{VH}$ & 4.49 & $\mathrm{VH}$ & 4.36 & VH \\
\hline
\end{tabular}

Legend

4.21-5.00

$3.41-4.20$

$2.61-3.40$

1.81-2.60

$1.00-1.80$
Very true (VeryHigh)

True (High)

Somewhat true (Moderate)

Not true (Low)

very untrue (Very Low)
As presented on the table, it manifests that as overall, the extrinsic motivation of basic public-school teachers in term of integrated regulation is 4.22 for male and 4.49 for female which is interpreted as very true or very high. Even as a whole, the extrinsic motivation in terms of integrated regulation is 4.36 which is considered as very true or very 
high. It means that teachers have integrated external values to become their own because these values are in congruence with their own values. In this case, they do their job because it has become a fundamental part of who they are (4.33), it is part of the way in which they have chosen to live their live (4.25) and such job is part of their lives (4.36).

Table 4. Summary Table?

\begin{tabular}{|l|l|l|}
\hline Summary & $\mathrm{X}$ & $\mathrm{DR}$ \\
\hline Integrated Regulation & 4.49 & $\mathrm{VH}$ \\
\hline Identified Regulation & 4.20 & $\mathrm{H}$ \\
\hline Introjected Regulation & 4.04 & $\mathrm{H}$ \\
\hline External Regulation & 4.16 & $\mathrm{H}$ \\
\hline Overall & 4.22 & $\mathrm{VH}$ \\
\hline
\end{tabular}

Legend

4.21-5.00

$3.41-4.20$

$2.61-3.40$

$1.81-2.60$

$1.00-1.80$

It is very clear from the data that overall, extrinsic motivation of basic public-school teachers of Metro Vigan and Caoayan is 4.22 which is understood as very true or very high. Taking it singly, it reveals that integrated regulation has the highest mean rating of 4.49 which is interpreted as very true or very high. It means that teachers have integrated external values to be their own values because those external values are aligned with their own values.

Problem 4: What is the job satisfaction of male and female employees of Public Basic Education of Metro Vigan and Caoayan, Philippines in terms of

Table 4a. Training and Development

\begin{tabular}{|c|c|c|c|c|c|c|}
\hline & Male & & Female & & As a whole & \\
\hline Training & $\begin{array}{l}\mathrm{X} \\
\end{array}$ & DR & $\mathrm{X}$ & DR & $\mathrm{X}$ & DR \\
\hline $\begin{array}{l}\text { 1. Enough training opportunities to allow me to perform my job } \\
\text { well }\end{array}$ & 4.49 & VS & 4.36 & VS & 4.43 & VS \\
\hline 2. Availability of follow-ups training & 4.20 & $\mathrm{~S}$ & 4.26 & VS & 4.23 & VS \\
\hline 3. Increase opportunities for advancement or professional growth & 4.44 & VS & 4.35 & VS & 4.40 & VS \\
\hline 4. Introducing seminar related to current job & 4.39 & $\mathrm{VS}$ & 4.41 & $\mathrm{VS}$ & 4.40 & $\mathrm{VS}$ \\
\hline 5. Empower me to participate in decisions that affect my work & 4.41 & VS & 4.28 & VS & 4.35 & VS \\
\hline Overall & 4.39 & VS & 4.33 & VS & 4.36 & VS \\
\hline
\end{tabular}

Legend

$4.21-5.00$

$3.41-4.20$

$2.61-3.40$

$1.81-2.60$

$1.00-1.80$
Very satisfied (Very High)

Satisfied (High)

Somewhat satisfied (Moderate)

Dissatisfied (Low)

Very dissatisfied (Very Low)
As reflected on the data gathered, it manifests that overall, the job satisfaction of basic public-school teachers in terms of training and development is 4.39 for male and 4.33 for female which is considered as very satisfied or very high. Taken as a whole, it also shows that the job satisfaction of basic public-school teachers in term of training and development is 4.36 which means very satisfied or very high.
Teacher are highly satisfied with training opportunities (4.49, 4.36), availability of follow ups training (4.20, 4.26), opportunities for profes sional growth $(4.44,4.35)$, seminars related to the job $(4.39,4.41)$ and empowerment $(4.41,4.28)$. Problem 4b: What is the job satisfaction of male and female employees of Public Basic Education of Metro Vigan and Caoayan, Philippines in terms of supervision? 


\begin{tabular}{|l|l|l|l|l|l|l|l|}
\hline \multicolumn{1}{|c|}{ Table 4b. Supervision } & Male & & Female & & As a whole & \\
\hline Supervision & X & DR & X & DR & X & DR \\
\hline $\begin{array}{l}\text { 1. Availability of immediate supervisor to answer your } \\
\text { questions and to assist you to carry out your duties }\end{array}$ & 4.37 & VS & 4.34 & VS & 4.36 & VS \\
\hline $\begin{array}{l}\text { 2. Frequent feedbacks and evaluations regarding your } \\
\text { performance }\end{array}$ & 4.17 & S & 4.21 & VS & 4.19 & S \\
\hline $\begin{array}{l}\text { 3. Recognition by my immediate supervisor for your } \\
\text { accomplishment }\end{array}$ & 4.32 & VS & 4.49 & VS & 4.41 & VS \\
\hline 4. Fair treatment to all employees & 4.12 & S & 4.22 & VS & 4.17 & S \\
\hline $\begin{array}{l}\text { 5. Supervisors monitor my work and often ask me about my } \\
\text { work }\end{array}$ & 4.00 & S & 4.16 & S & 4.08 & S \\
\hline Overall & 4.20 & S & 4.28 & VS & 4.24 & VS \\
\hline
\end{tabular}

Legend

4.21-5.00

Very satisfied (Very High)

$3.41-4.20$

Satisfied (High)

$2.61-3.40$

Somewhat satisfied (Moderate)

$1.81-2.60$

Dissatisfied (Low)

$1.00-1.80$

Very dissatisfied (Very Low)

As it is manifested on the mean rating, it appears that job satisfaction of basic public-school teachers in Metro Vigan and Caoayan in terms of supervision is 4.20 for male and 4.28 for female which is interpreted as satisfied and very satisfied respectively. However, taken as a whole, the mean rating indicates that job satisfaction in terms of supervision is 4.24 which is understood as very satisfied or very high. It just means that basic public school teachers in Metro Vigan and Caoayan are still very satisfied or very highly satisfied with the supervision in terms of the availability of supervisors to

answer and assist them in their difficulties (4.36), frequency of feedback regarding their performance (4.19), recognition from their supervis or for their accomplishment (4.41), fair treatment for all employees (4.17) and monitoring and asking questions related to the work of the employees (4.08).

Problem 4c: What is the job satisfaction of male and female employees of Public Basic Education of Metro Vigan and Caoayan, Ilocos Sur, Philippines in terms of compensation and benefits?

Table 4c. Compensation and Benefits

\begin{tabular}{|l|l|l|l|l|l|}
\hline & Male & Female & As a whole & \\
\hline Compensation & $\mathrm{X}$ & $\mathrm{DR}$ & $\mathrm{X}$ & $\mathrm{DR}$ & $\mathrm{X}$ \\
\hline 1. Your rate of pay for your work & 4.24 & $\mathrm{VS}$ & 3.95 & $\mathrm{~S}$ & 4.10 \\
\hline 2. There are enough benefits given to employees & 4.17 & $\mathrm{~S}$ & 3.90 & $\mathrm{~S}$ & 4.04 \\
\hline $\begin{array}{l}\text { 3. Improve benefits such as sick leave, vacation leaves, } \\
\text { dependent privileges and retirement }\end{array}$ & 4.17 & $\mathrm{~S}$ & 3.94 & $\mathrm{~S}$ & 4.06 \\
\hline $\begin{array}{l}\text { 4. Provide further education assistance } \\
\text { 5. Provides free uniform }\end{array}$ & 4.07 & $\mathrm{~S}$ & 3.99 & $\mathrm{~S}$ & 4.03 \\
\hline Overall & 4.07 & $\mathrm{~S}$ & 4.35 & $\mathrm{VS}$ & 4.21 \\
\hline
\end{tabular}

Legend

4.21-5.00

$3.41-4.20$

$2.61-3.40$

$1.81-2.60$

$1.00-1.80$
Very satisfied (Very High)

Satisfied (high)

Somewhat satisfied (Moderate)

Dissatisfied (Low)

Very dissatisfied (Very Low) 
Based on the computed data, it reveals that overall, the job satisfaction of teachers in terms compensation and benefits is 4.49 for male and 4.02 for female which is translated as very satisfied and satisfied respectively. It shows a different mean rating in which male teachers are very satisfied and female teachers are satisfied only. However, when taken, job satisfaction of teachers along with compensation and benefits is 4.26 which is considered as very satisfied or very high. It means that as a whole, teachers are very satisfied with their rate pay, benefits, education as sistance, and uniform.

Problem 4c: What is the job satisfaction of male and female employees of Public Basic Education of Metro Vigan and Caoayan, Ilocos Sur, Philippines in terms of working relationship?

Table $4 d$. Working relationship?

\begin{tabular}{|l|l|l|l|l|l|l|}
\hline working relationship & Male & & Female & & As a whole & \\
\hline & $\mathrm{X}$ & $\mathrm{DR}$ & $\mathrm{X}$ & $\mathrm{DR}$ & $\mathrm{X}$ \\
\hline $\begin{array}{l}\text { 1. Reduce conflict between employees and improve } \\
\text { team building }\end{array}$ & 4.00 & $\mathrm{~S}$ & 4.22 & $\mathrm{VS}$ & 4.11 \\
\hline 2. Improve supervis or - employee's relations & 4.17 & $\mathrm{~S}$ & 4.29 & $\mathrm{VS}$ & 4.23 \\
\hline $\begin{array}{l}\text { 3. Improve communications between supervisor and } \\
\text { subordinates }\end{array}$ & 4.10 & $\mathrm{~S}$ & 4.23 & $\mathrm{VS}$ & 4.17 & $\mathrm{VS}$ \\
\hline 4. Reduce conflict with supervisor & 4.07 & $\mathrm{~S}$ & 4.25 & $\mathrm{VS}$ & 4.16 \\
\hline 5. The employees are team players & 4.12 & $\mathrm{~S}$ & 4.34 & $\mathrm{VS}$ & 4.23 & $\mathrm{~S}$ \\
\hline Overall & 4.09 & $\mathrm{~S}$ & 4.27 & $\mathrm{VS}$ & 4.18 \\
\hline & & & & & $\mathrm{VS}$ \\
\hline
\end{tabular}

Legend

4.21-5.00

$3.41-4.20$

$2.61-3.40$

$1.81-2.60$

$1.00-1.80$

\author{
Very satisfied (Very High) \\ Satisfied (High) \\ Somewhat satisfied (Moderate) \\ Dissatisfied (Low) \\ Very dissatisfied (Very Low)
}

As it is indicated in the mean rating, it reveals that overall, the job satisfaction of teachers in terms of working relationship is 4.09 for male and 4.27 for female which is interpreted as satisfied and very satisfied respectively. It appears that female is higher than male in terms of satisfaction along working relationship. Though female is higher than male in terms of working relationship, however when taken them as a whole, both male and female have job satisfaction rating of 4.18 which is considered as satisfied or high only. In indicates that both are satisfied or highly satisfied with their working relationship between teachers and supervisors and between teachers.

Table 5: Summary table

\begin{tabular}{|l|l|l|}
\hline Summary & $\mathrm{X}$ & $\mathrm{DR}$ \\
\hline Training and development & 4.33 & $\mathrm{VH}$ \\
\hline Supervision & 4.28 & $\mathrm{VH}$ \\
\hline Compens ation and benefits & 4.02 & $\mathrm{H}$ \\
\hline working relationship & 4.27 & $\mathrm{VH}$ \\
\hline Overall & 4.23 & $\mathrm{VH}$ \\
\hline
\end{tabular}

Legend

4.21-5.00

$3.41-4.20$

$2.61-3.40$

$1.81-2.60$

$1.00-1.80$

Very satisfied (Very High)

Satisfied (High)

Somewhat satisfied (Moderate)

Dissatisfied (Low)

Very dissatisfied (Very Low)

As revealed from the summary table, it shows that overall, the job satisfaction of basic public school in Metro Vigan and Caoayan is 4.23 which is considered as very satisfied or very high. Such rating indicates that teachers are very satisfied in terms of training and development (4.33), supervision (4.28), working relationship with supervis ors and among employees (4.27). There is only one variable in which the teachers are not very satisfied which is compensation and benefits (4.02).

Problem 5: Is there a relationship between work motivation of male and female employees of Public Education of Metro Vigan and Caoayan, Philippines and their job satisfaction? 
Table 6: Relationship between work motivation of male and female and job satisfaction.

\begin{tabular}{|l|l|}
\hline & \\
\hline Intrinsic regulation & 0.0745 \\
\hline Integrated regulation & 0.1482 \\
\hline Identified regulation & 0.0439 \\
\hline Introjected regulation & 0.0602 \\
\hline External regulation & -0.0187 \\
\hline As a whole & 0.0616 \\
\hline
\end{tabular}

*Significant at .05 level (2-tailed)

As shown in the data, it reveals that as a whole, there is no relationship between work motivation of male and female teachers and their job satisfaction. Even when taking them singly, all variables under intrinsic and extrinsic motivation does not correlate to job satisfaction.

Problem 6: Is there a difference between motivation of male and female employees?

Table 7: The difference between work motivation of male and female employees.

Significant at .05 level(2-tailed)

\begin{tabular}{|l|l|l|l|l|}
\hline & $\mathrm{t}$-computed & $\mathrm{X} 1$ & $\mathrm{X} 2$ & \\
\hline Intrinsic motivation & -1.1728 & 4.32 & 4.45 & not significant \\
\hline Integrated regulation & $-2.0245^{*}$ & 4.22 & 4.49 & Significant \\
\hline Identified regulation & -0.9099 & 4.11 & 4.20 & not significant \\
\hline Introjected regulation & -1.072 & 3.89 & 4.04 & not significant \\
\hline External regulation & 0.2549 & 4.19 & 4.16 & not significant \\
\hline
\end{tabular}

Based on the t-test computation, it shows that, as a whole, there is no significant difference between work motivation between male and female teachers of basic public school in Metro Vigan and Caoayan. Taking it singly, it reveals that there is a significant difference between work motivation of male and female teachers in terms of integrated regulation.

Problem 7: Is there a difference between job satisfaction of male and female employees?

Table 8: The Difference between job satisfaction of male and female employees.

Significant at .05 level (2-tailed)

\begin{tabular}{|l|l|l|l|l|}
\hline & $\mathrm{t}$-computed & $\mathrm{X} 1$ & $\mathrm{X} 2$ & decision \\
\hline training & 0.6462 & 4.39 & 4.33 & not significant \\
\hline supervision & -0.8503 & 4.20 & 4.28 & not significant \\
\hline compensation & 1.9313 & 4.23 & 4.03 & not significant \\
\hline $\begin{array}{l}\text { working } \\
\text { relationship }\end{array}$ & -1.7351 & 4.09 & 4.27 & not significant \\
\hline & & & & \\
\hline
\end{tabular}

As gleaned from t-test computation, the data manifests that as a whole, there is no significant difference between job satisfaction of male and female teachers. Even when taking them singly, it appears that all variables do not show a significant difference between job satisfactions of both genders.

\section{CONCLUSION}

From the findings, the study concludes that majority of teachers of basic public school in Metro Vigan and Caoayan is female (84.41\%). Their intrinsic motivation and extrinsic motivation are very high and also their job satisfaction got a very high rating (4.23) and that there is no relationship between work motivation and job satisfaction. It is also found that overall, there was no difference in terms of motivation but taking it singly, there was a difference in terms of integrated regulation.

The study also reveals that there is no difference between job satisfaction of male and female teachers in basic public school in Metro Vigan and Caoayan.

\section{REFERENCES}

[1] Abdullah, F.Z., Teng, S.S. \& Bustaman, F.L. (2014). Reward Management and Job Satisfaction among Frontline Employees in Hotel Industry in Malaysia. Procedia-Social and Behavioral Sciences, Vol. 44, 20 August 2014, Pages 392-40. 
[2] Alderfer, Clayton P. (1969). "An empirical test of a new theory of human needs". Organizational Behavior and Human Performance. 4 (2): 142-75. doi: 10.1016/00305073(69)90004-X.

[3] Allabout careers (n.d). Human Resources: Compensation, Benefits and Rewards. Retrieved from https://www.allaboutcareers.com/careers/careerpath/human-resources-compensation-benefits-reward

[4] Ariola, M.M. (2006). Principles and Methods of Research. Manila: Rex Bookstore.

[5] Azim, M.T., Haque, M.M. \& Chowdhury, R.A. (2013). Gender, Marital Status and Job Satisfaction an Empirical Study. International Review of Management and Business Research Vol. 2 Issue.2.

[6] Aziri, B. Job satisfaction: A Literature Review. Management Research and Practice, Vol. 3, Issue, 4 (2011) pp. 77-86.

[7] Baumeister, R.; Leary, M. R. (1995). "The need to belong: Desire for interpersonal attachments as a fundamental human motivation". Psychological Bulletin. 117: 497-529. doi: $10.1037 / 0033$ 2909.117.3.497. PMID 7777651.

[8] Bazan, K. (2009). Motivation and Job Satisfaction: Crucial Factors that Impact Employees' Long-Term Job Satisfaction and Personal Growth. Unpublished Master Thesis, Adler Graduate School, Minnesota.

[9] Best, J.W. \& Khan, J.V. (1993). Research in Education. New Jersey: Prentice Hall, Inc.

[10] Blanchard, C.M., Tremblay, M.A., Taylor, S., Pelletier, L.G., \& Villeneuve, M. (2009). Canadian Journal of Behavioral Science, 2009, Vol. 14, No. 4, pp. 213-226.

[11] Brown, J. \& Sheppard, B. (1997). Teacher librarians in learning organizations. Paper Presented at the Annual Conference of the International Association of School Librarianship, Canada. August 25-30.

[12] Burks, F. (2018). Are There Motivational Differences in Genders in the Workplace? Chron. Retrieved from https://smallbusiness.chron.com/there-motivationaldifferences-genders-workplace-12620.ht ml.

[13] Clark, A.E. Job satisfaction and gender: Why are women so happy at work? Labour Economics, Vol.4, Issue, 4, December 1997, Pages 341-372,

[14] Cool, L.C. (n.d). Are Male and Female Brains Different? WebMD: Brain and Nervous System Home. Retrieved from https://www.webmd.com/brain/features/how-malefemale-brains-differ\# 1

[15] Danish, R.Q. (2010). Impact of Reward and Recognition on Job Satisfaction and Motivation: An
Empirical Study from Pakistan. International Journal of Business Management, Vol. 5, No.2, February 2010.

[16] Deci, E.L. \& Ryan, R.M. (2000). The "What" and "Why" of Goal Pursuits: Human Needs and the SelfDetermination behavior. Psychological Inquiry, 2000, Vol. 11, no. 4, pp.227-268

[17] Deci, E. L. (1975). Intrinsic motivation. New York: Plenum.

[18] Deci, E.L. \& Ryan, R.M. (1971). Effects of Externally Mediated Rewards on Intrinsic Motivation. Journal of Personality and Social Psychology, Vol. 18, No.1, pp. 105-115

[19] deCharms, R. (1968). Personal causation. New York: Academic Press.

[20] Alderfer, C, P. (1969). "An empirical test of a new theory of human needs". Organizational Behavior and Human Performance. 4 (2): 142-75. doi: $10.1016 / 0030-$ 5073(69)90004-X.

[21] Dovey, D. (2014). Differences in Male and Female Brains Make Us Susceptible to Different Psychiatric Disorders. Medical Daily. Retrieved from https://www.medicaldaily.com/diffe rences -male-andfemale-brains-make-us-susceptible-differentpsychiatric-disorders-284958.

[22] Erat, S., Akcin, K., Alniacik, E. \& Alniacik, U. (2012). Relationship between Career Motivation, Affective Commitment and Job satisfaction. Procedia-Social and Behavioral Sciences, Vol. 58, 12 October 2012, Pages 355-362

[23] Essays, UK. (November 2013). Relationship between Work Motivation and Job Satisfaction. Retrieved from https://www.ukessays.com/essays/psychology/relation ship-between-work-motivation-and-job-satisfactionpsychology-essay.php?vref=1

[24] Essays, UK. (November 2013). Motivation Across Cultures. Retrieved from https://www.ukessays.com/essays/psychology/relation ship-between-work-motivation-and-job-satisfactionpsychology-essay.php?vref=1.

[25] Fatima, N., Iqbal, S., Akhwand, s.Y., \& Suleman, M. (2015). International Journal of Economics, Finance and Management Sciences 2015; 3(1): 27-33.

[26] Gagne, M., \& Deci, E.L. (2005). Self-Determination Theory and Work Motivation. Journal of Organizational Behavior. Vol. 26, pp. 331-362.

[27] Halici, A. (2012). Importance of the Motivational Factors Affecting Employees Satisfaction. International Business Research Vol. 5, No. 1; January 2012. 
[28] Harter, S (1978). "Effectance motivation reconsidered: Toward a developmental model". Human Development. 1: 661-669.

[29] Hartzell, S. (n.d). The Needs Theory: Motivating Employees with Maslow's Hierarchy of Needs. Retrieved from https://study.com/academy/les son/theneeds-theory-motivating-employees-with-mas lowshierarchy-of-needs.html.

[30] Herzberg, F., Mausner, B., Snyderman, B, B. (1959). The Motivation to Work (2nd ed.). New York: John Wiley. ISBN $\underline{0471373893}$.

[31] Hrcouncil.ca (n.d). Compensation and Benefits. Retrieved from http://www.hrcouncil.ca/hrtoolkit/defining-compens ation.cfm.

[32] Jantz, G.L. (2014). Brain Differences Between Gender. Psychology Today. Retrieved from https://www.psychologytoday.com/us/blog/hoperelationships/201402/brain-differences-betweengenders.

[33] Jehanzeb, K., Rasheed, M.F., Rasheed, A., \&Amir, A. (2012). Impacts of Rewards and Motivation in Banking Sector of Saudi Arabia. International Journal of Business and Social Science Vol. 3 No. 21; November 2012.

[34] Jodai, Hojat; Zafarghandi, Amir Mahda Vi; Tous, Maryam Danaye (2013-01-01). "Motivation, Integrativeness, Organizational Influence, Anxiety, and English

Achievement". Glottotheory. 4 (2). doi:10.1524/glot.2 013.0012. ISSN 2196-690.

[35] Jordan, B. (2017). Management and Supervision Vs. Leadership. About Leaders. Retrieved from https://aboutleaders.com/management-andsupervision-vs-leadership/\#gs.lu0uB18

[36] Kim, S. (2015). Gender Differences in the Job Satisfaction of Public Employees: A Study of Seoul Metropolitan Government, Korea. Sex Roles, 2005, Volume 52, Number 9-10, Page 667

[37] Kleiman, C. (2004). Supervisors Vital to Job Satisfaction. Chicago Tribune. Retrieved from http://articles .chicagotribune.com/2004-01-

22/business/0401220369_1_tulgan-points-supervisorsjob-satisfaction.

[38] Landy, F. J. (1985). Psychology of work behavior. Homewood, IL: Dorsey Press

[39] Mabekoje, S.O. (2009). Gender Differences in Job Satisfaction among Secondary School Teachers. African Journal of Research in Personnel and
Counselling Psychology (AJRPCP) 2009, 1 (1), 99108.

[40] McClelland, D. (1961). The achieving society. Princeton, NJ: Van Nostrand Company Inc

[41] McClelland, D. C. (1980). Motive dispositions: The merits of operant and respondent measures. In L. Wheeler (Ed.), Review of personality and social psychology, (Vol. 1, pp. 53-81). Beverly Hills, CA: Sage.

[42] Miller, H. (2007). Difference Between Male and Female Structure (Mental and Physical). Steady Health. Retrieved from https://www.steadyhealth.com/articles/differencebetween-male-and-female-structures-mental-andphysica.1

[43] Mustapha, N. (2013). The Influence of Financial Reward on Job Satisfaction among Academic Staffs at Public Universities in Kelantan, Malaysia. International Journal of Business and Social Science Vol. 4 No. 3; March 2013.

[44] O’Brien, P. (2014). Why Strong Employer/Employee Relationship is Important and How to Achieve This? B 2 C: Business 2 Community. Retrieved from https://www.busines s 2community.com/strategy/strong -employeeemployer-relationship-important-achieve0876781.

[45] Pardee, R. L. (1990). Motivation Theories of Maslow, Herzberg, McGregor \& McClelland. A Literature Review of Selected Theories Dealing with Job Satisfaction and Motivation. Educational Resources Information Center (ERIC). Retrieved from https://eric.ed.gov/?id=ED316767,

[46] Patrick, J. (2000). Training. In N. Chmiel (Ed.), Introduction to Work and Organizational Psychology (pp. 100-125), Oxford, UK: Blackwell.

[47] Priya, T.U., \& Eshwar, T.S. (2014). Rewards, Motivation and Job satisfaction of Employees in Commercial Banks-An Investigative Analysis. International Journal of Academic Research in Business and Social Sciences April 2014, Vol. 4, No. 4.

[48] Qureshi, H. (2016). Benefits of Training and Development in Organization. Kashmir Observer. Retrieved from https://kas hmirobserver.net/2016/opinions/benefits training-development-organization-3983.

[49] Rohrbeck, Cynthia. (1988). The Relationship between Gender and Job Satisfaction in High-School Students Employed Part-lime. Conference: Conference: 
American Educational Research Association, At New Orleans, Volume: ERIC Number: ED300728.

[50] Romanes, G.J. (1887). Mental Differences of Men and Women. Wikisoure: Popular Science Monthly, Vol. 31, July $1887 . \quad$ Retrieved from https://en.wikis ource.org/wiki/Popular_Science_Mont hly/Volume_31/July_1887/Mental_Differences_of_M en_and_Women.

[51] Ryan, R.M, \& Deci, E.L. (2002). Self-Determination Theory and the Facilitation of Intrinsic Motivation, Social Development and Well-Being. American Psychology, 55, 68-78

[52] Schmidt, S.W. (2007). The Relationship between Satisfaction with Workplace Training and Overall Job Satisfaction. Human Resources Quarterly, Vol. 18, Is sue 4, pp. 481-498. DOI: 10.1002/hrdq.1216.

[53] Schreiner, E (2018). What is an Employer-Employee Relationship? Chron. Retrieved from https://s mallbusines s.chron.com/employeremployeerelationship-16737.html

[54] Singh, J.K., \& Jain, M. (2013). A Study of Employees' Job satisfaction and Its Impact on their Performance. Journal of Indian Research, Vol. 1, No.4, pp. 105-111.

[55] Study Mode Resarch (2013). Understanding Professional Supervision Practice. Retrieved from https://www.studymode.com/es says/UnderstandingProfes sional-Supervision-Practice-43163236.html.

[56] Tausif, M. (2012). Influence of Non-Financial Rewards on Job Satisfaction: A Case Study of Educational Sector of Pakistan. Asian Journal of Management Research, Vol. 2, No. 2, 2012.

[57] Tella, A., \& Ayeni, C.O. (2007). Work Motivation, Job Satisfaction, and Organizational Commitment of Library Personnel in Academic and Research Libraries in Oyo State, Nigeria. Library Philosophy and Practice (e.journal). University of Nebraska-Lincoln.

[58] White, R. W. (1963). Ego and reality in psychoanalytic theory. New York: International Universities Press.

[59] William, G.C., Grow, V.M., Freedman, Z., Ryan, R.M. \& Deci, E.L. (1996). Motivational Preditctors of Weight Loss and Weight Loss Maintenance. Journal of Personality and Social Psychology, 70, 115-126.

[60] Yip, P. (2018). Importance of Employee relations - Why Employee Relations at Workplace? MSG: Management Study Guide. Retrieved from https://www.managements tudyguide.com/importanceof-employee-relations.htm

[61] Yip, P. (2018). Training and Development: Meaning, Its Need and Importance. MSG: Management Study
Guide.

Retrieved

from

https://www.managementstudyguide.com/training and-development.htm.

[62] Patrick, J. (2000). Training. In N. Chmiel (Ed.), Introduction to work and organizational psychology (pp. 100-125). Oxford, UK: Blackwell

[63] Patrick, J. (2000). Training. In N. Chmiel (Ed.), Introduction to work and organizational psychology (pp. 100-125). Oxford, UK: Blackwell

[64] Patrick, J. (2000). Training. In N. Chmiel (Ed.), Introduction to work and organizational psychology (pp. 100-125). Oxford, UK: Blackwell 